\title{
ANALISIS WACANA MEDIA TERHADAP KEBIJAKAN DAN CITRA PEMERINTAH DI SURAT KABAR DAERAH PADA TAHUN 2017
}

\section{MEDIA DISCOURSE ANALYSIS OF GOVERNMENT POLICY AND IMAGE IN LOCAL NEWSPAPERS IN 2017}

\author{
Syarif Budhirianto ${ }^{1}$, Noneng Sumiaty ${ }^{2}$, Syaidah $^{3}$ \\ Balai Pengembangan SDM dan Penelitian Komunikasi dan Informatika Bandung J1.Pajajaran No.88 \\ Bandung, Jawa Barat - 40173, Telp.022-6017493, Fax.022-6021740 \\ ${ }^{1}$ syarifbudhi@gmail.com, ${ }^{2}$ nsumiaty62@gmail.com, ${ }^{3}$ syai001@ kominfo.go.id
}

Diterima : 20 Juli 2018

Direvisi : 06 September 2018

Disetujui : 12 Oktober 2018

\begin{abstract}
Newspaper as a news messenger to the public has two agendas: media and public policy. The problem is how newspapers set their agendas towards current government policies, media representations and their tone of news coverage.The purpose is to identify the agenda setting, media representations and news tone of four local newspapers towards the government policies. This study is descriptive, taking samples by systematic random sampling from each issue of four newspapers, i.e. Pikiran Rakyat, Radar Banten, Sumatera Ekspres, and Tribun Lampung. Results of the analysis show that the news agenda of government program and policy predominantly contains news of human development and local news. Media frame has created an image that helps shape the public opinions of a popular figure or governmental institution. The news tone tends to support government policies.
\end{abstract}

Keywords: Agenda Setting, Government Policy Program, Media Representations and News Tone

\begin{abstract}
ABSTRAK
Surat kabar sebagai penyampai berita kepada masyarakat mempunyai agenda media dan agenda kebijakan publik. Permasalahannya adalah bagaimana agenda pemberitaan, citra dan sikap surat kabar terhadap program kebijakan pemerintah saat ini. Tujuannya adalah melakukan analisis terhadap agenda setting, citra dan sikap surat kabar terhadap kebijakan pemerintah,. Studi ini bersifat deskriptif, dengan teknik pengambilan sampel systematic random sampling dari setiap edisi dari empat surat kabar, yakni Pikiran Rakyat, Radar Banten, Sumatera Ekspres, dan Tribun Lampung. Hasil analisis menunjukkan bahwa agenda pemberitaan program dan kebijakan pemerintah lebih banyak berisi rubrik pembangunan masyarakat dan berita daerah. Pembingkaian berita telah memunculkan pencitraan yang membentuk opini publik terhadap tokoh maupun institusi pemerintahan. Adapun sikap media, yang tampak dari news tone atau nada pemberitaannya adalah cenderung mendukung kebijakan pemerintah.
\end{abstract}

Kata Kunci: Agenda Setting, Program Kebijakan Pemerintah, Citra dan Sikap

\section{PENDAHULUAN}

Di tengah kemajuan media baru yang berbasis online, keberadaan surat kabar masih diperlukan khalayak sebagai media informasi dan komunikasi. Meskipun kalah bersaing dari sisi aktualitas, media ini memiliki kelebihan pada agenda dan seleksi berita yang diramu sedemikian rupa sehingga menghasilkan format berita yang menarik. Mulai halaman pertama hingga terakhir, surat kabar menyajikan berita tentang dinamika sosial yang tersusun sesuai agenda media.

Media cetak sebagai salah satu sarana untuk menyampaikan berita, penilaian atau membentuk citra tentang banyak hal, juga mempunyai kemampuan untuk berperan 
sebagai institusi yang dapat membentuk opini publik. Media dapat menghadirkan citra atas sebuah pemberitaan. Citra ataupun sikap tersebut terbentuk dari realitas yang ditampilkan oleh media. Realitas yang didapatkan melalui media adalah second hand reality, realitas yang sudah diseleksi melalui proses yang disebut gatekeeping.

Dengan demikian, seluruh isi media merupakan realitas yang telah dikonstruksikan dalam bentuk wacana yang bermakna. Media akan mampu membuat beberapa isu menjadi lebih penting dari yang lainnya, sehingga mampu memengaruhi pikiran pembaca. Lebih dari itu, sebagai salah satu media, surat kabar dipercaya dapat memengaruhi cara masyarakat berpikir, yang oleh para ilmuwan disebut sebagai framing .

Sebagai salah satu kekuatan yang mampu mendorong perubahan opini publik, media massa mampu melakukan pembentukan citra dan sikap terhadap sebuah objek pemberitaan. Citra seorang tokoh, lembaga/ institusi bahkan suatu negara bisa terangkat atau jatuh karena pemberitaan media. Huddleston (Alma, 2008) memberikan pengertian tentang citra dengan mengatakan sebagai berikut, "Image is a set of beliefs the personal associate with an image as acquired through experience”. Artinya, citra adalah serangkaian kepercayaan yang dihubungkan dengan sebuah gambaran yang dimiliki atau didapat dari pengalaman. Demikian juga dengan Kabinet Kerja pemerintahan JokowiJK yang diharapkan membawa harapan baru di masyarakat. Dalam hal ini, media memiliki kontribusi dalam memberikan pengaruh positif terhadap pembentukan opini masyarakat mengenai kinerja pemerintahan saat ini. Di sisi lain, pencitraan tersebut mendapat kritik konstruktif dari berbagai kalangan.
Meskipun ekspos media belum tentu mewakili kinerja pemerintahan, media dapat membentuk persepsi masyarakat, sehingga terciptalah citra tentang kinerja pemerintahan, terutama di setiap kementerian dan lembaga non kementerian. Selain sebagai sarana untuk menyampaikan berita tentang banyak hal, media juga berperan sebagai institusi untuk membentuk pencitraan kepada khalayak pembaca. Ramsden (1992) menyatakan, publik kebanyakan menyandarkan informasi politik mereka kepada media dan informasi tersebut mampu memengaruhi persepsi publik.

Dengan menimbang peran media sebagai sumber informasi khalayak tentang kebijakan pemerintah, maka studi ini menyoroti agenda surat kabar dalam memberitakan kinerja kementerian/lembaga pemerintahan Presiden Jokowi-JK di dalam Kabinet Kerja tahun 2017 dan kebijakan pemerintah daerah dalam membentuk citra dan sikap pemerintahan di surat kabar. Konteks pemerintah yang dimaksud adalah Kabinet Kerja yang terdiri dari 4 (empat) menteri koordinator dan 30 menteri yang diangkat langsung dan bertanggung jawab kepada Presiden.

Tujuan analisis media ini adalah untuk mengetahui kecenderungan pencitraan masyarakat sesuai agenda setting pada setiap konten berita yang disajikan. Dengan demikian, realitas opini publik yang terbentuk dapat dijadikan referensi konstruktif bagi aparat pemerintah dalam meningkatkan pelayanan publik. Adapun kegunaan studi ini bagi Kementerian Komunikasi dan Informatika adalah dapat dijadikan salah satu referensi dalam pembuatan kebijakan di bidang perencanaan program dan strategi komunikasi Government Public Relations (GPR), serta sebagai bahan evaluasi kinerja 
pemerintahan baik di tingkat pusat maupun daerah.

Studi atau penelitian tentang kinerja Kabinet Kerja tidak hanya dilaksanakan oleh kalangan akademisi namun juga oleh lembaga atau institusi penelitian, di antaranya sebagai berikut: (1) Lingkaran Survei Indonesia, pasca setahun pemerintahan Jokowi-JK. Survei ini dilakukan melalui quick poll tanggal 25-27 Oktober 2015 terhadap 600 responden dan ditunjang penelitian kualitatif dengan metode analisis media, FGD dan in depth interview, yang hasilnya menyimpulkan bahwa mayoritas publik $(64,63 \%)$ menyatakan bahwa pemerintahan Jokowi memerlukan semacam menteri utama agar kinerjanya lebih baik, meskipun secara ketatanegaraan keberadaannya diperdebatkan. Dukungan tersebut merata di semua segmen masyarakat, baik mereka yang tinggal di perdesaan ataupun perkotaan, berpendidikan rendah ataupun tinggi, latar belakang perekonomian rendah ataupun mapan. (Denny, 2015); (2) Konstruksi pemberitaan media online tentang kinerja Kabinet Kerja Jokowi-JK Dari keseluruhan analisis konstruksi media atas realitas politik, kinerja kabinet dicitrakan detik.com sebagai bentuk nyata kerja menteri dan presiden, sehingga perspektif masyarakat tentang Kabinet Kerja menjadi baik, sedangkan konstruksi realitas yang dibangun viva.co.id cenderung dipolitisasi oleh pemilik media. Viva.co.id cenderung melansir berita yang provokatif terhadap Kabinet Kerja dengan menyatakan bahwa Kabinet Kerja sengaja melakukan pencitraan dengan kegiatan blusukan. Jika hal ini tetap dibiarkan, akan timbul masalah jika hasil konstruksi tersebut dijadikan rujukan oleh masyarakat (Dalilah, 2015); (3) Kabinet Alternatif Usulan Rakyat
(KAUR) yang menyoroti pemberitaan pemerintahan Kabinet Kerja di media massa, termasuk berbagai kebijakan di periode awal pemerintahan Kabinet Kerja (http://pindai.org/ 2015/02/03/100-hari-jokowi-di-mata-media/). Screening dilakukan di mesin pencari dari empat portal dengan melakukan penarikan sampel secara acak proporsional dengan tingkat kepercayaan $95 \%$ dan nilai kesalahan (sampling eror) 5\%, sehingga diperoleh 467 sampel. Secara umum, nada pemberitaan atas isu kebijakan Jokowi bersifat negatif. Bahkan, opini netral terhadap pemberitaan tersebut tetap diartikan negatif sebagai bentuk ketidakpedulian atau kritik terhadap kebijakan yang diambil.

Berdasarkan kajian yang dilakukan oleh lembaga/institusi penelitian tersebut, diperoleh fakta bahwa pemberitaan media umumnya lebih sering mengangkat pandangan kelompok kritis dibandingkan informasi dari pejabat pemerintah. Di samping itu, analisis yang dilakukan dengan teknik quick poll dalam merekonstruksi berita kinerja Jokowi-JK hanya berdasar pada realitas politik yang ada tanpa mempertimbangkan variabel lain secara keseluruhan sehingga pemberitaan seringkali menjadi tidak berimbang. Kecenderungan tersebut dapat memberi pengaruh terhadap pembentukan opini publik mengenai kinerja pemerintah. Pembentukan citra bisa berdampak ke berbagai sektor, sehingga citra pemerintah yang kurang baik di mata rakyat dapat mengakibatkan rendahnya kepercayaan publik terhadap pemerintah. Penelitian ini berusaha mendorong agar pemberitaan media mengenai kinerja pemerintah menjadi lebih proporsional. Evaluasi terhadap kinerja pemerintah hendaknya dilakukan dengan mengacu pada prinsip tata kelola pemerintah 
yang baik (good governance) yang menekankan pada asas tranparansi, akuntabilitas, dan partisipasi masyarakat.

McCombs dan Shaw menegaskan tentang teori agenda setting, bahwa "the media may not only tell us what to think about, they also may tell us how and what to think about it, and perhaps even what to do about it" (McCombs, 1997). Menurut teori agenda setting, media massa memang tidak dapat memengaruhi orang untuk berubah sikap tetapi dengan fungsinya sebagai gatekeeper (penjaga gawang atau penyaring), media massa dapat memilih untuk memberitakan suatu topik atau persoalan tertentu dan mengabaikan yang lain.

\section{Agenda Setting menggambarkan} kuatnya pengaruh media terhadap pembentukan opini masyarakat, karena media memberi tekanan pada suatu peristiwa maka media itu akan memengaruhi khalayak untuk menganggapnya penting (Rakhmat, 2007). Littlejohn (2005) mengatakan, agenda setting beroperasi dalam tiga bagian, yaitu: 1. Format agenda media. Proses ini akan menjelaskan awal terbentuknya agenda media; 2. Agenda media memengaruhi atau berinteraksi dengan agenda publik. Pernyataan ini memunculkan pertanyaan, seberapa besar kekuatan media dalam memengaruhi agenda publik dan bagaimana publik membentuknya; 3. Agenda publik memengaruhi atau berinteraksi dengan agenda kebijakan. Agenda kebijakan adalah pembuatan kebijakan publik yang dianggap penting bagi masyarakat.

Dalam agenda setting dikenal tiga agenda. yaitu 1) Agenda Media; 2) Agenda Publik; 3) Agenda Kebijakan. Masing-masing agenda saling memengaruhi, khususnya antara agenda kebijakan dan agenda media. Pemerintah berupaya mengomunikasikan agenda kebijakan melalui media agar sampai ke publik. Sementara itu, media melalui pemberitaannya berupaya mendesakkan agendanya kepada pemerintah guna memengaruhi dan/atau mengubah kebijakannya sehingga sesuai dengan aspirasi publik (agenda publik). Proses agenda setting tersebut digambarkan dalam diagram berikut.

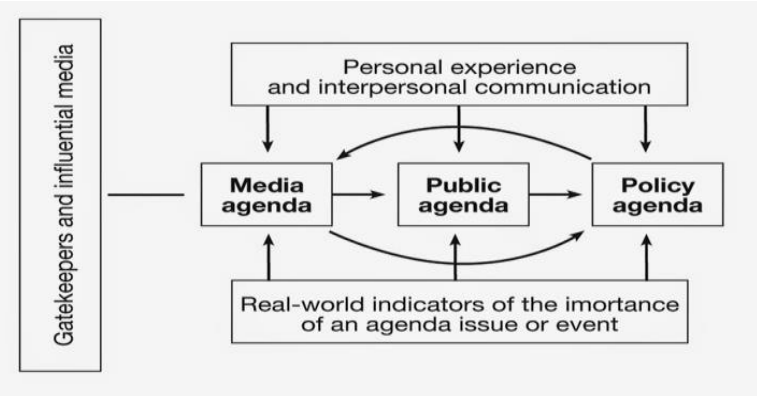

Gambar 1. Proses Agenda Setting oleh Media Sumber: Tamburaka. 2012.

\section{METODOLOGI PENELITIAN}

Penelitian ini bersifat deskriptif, yang merupakan metode untuk menggambarkan hasil penelusuran informasi ke fakta yang diolah menjadi data (Kriyantono, 2007). Studi ini menggunakan analisis isi kuantitatif dengan pendekatan agenda setting. Dalam analisis ini dilakukan pemrosesan informasi konten berita dengan membuat kategorisasi dan tabulasi, baik dalam bentuk tabel frekuensi tunggal maupun silang atau gambar grafik.

Surat kabar yang diambil sebagai sampel adalah surat kabar Pikiran Rakyat dari Jawa Barat, surat kabar Radar Banten, surat kabar Sumatera Ekspres dari Sumatera Selatan, dan surat kabar Tribun Lampung, untuk periode 1 Januari-30 September 2017. Keempat surat kabar tersebut menguasai pangsa pasar media lokal, dengan jumlah pelanggan dan sirkulasi tertinggi dibanding surat kabar lokal lainnya. Keempat surat kabar tersebut juga menjadi acuan masyarakat sehingga menunjukkan 
bahwa agenda setting surat kabar tersebut lebih dipercaya sebagai sumber berita.

Unit analisis dalam penelitian ini adalah lingkup pemberitaan yang terkait dengan program kebijakan kinerja kementerian/lembaga pemerintahan JokowiJK dalam Kabinet Kerja tahun 2017, serta kebijakan pemerintah daerah dalam membentuk citra pemerintahan di surat kabar. Aspek pemberitaan informasi dasar meliputi penjabaran 3 (tiga) dimensi pembangunan yang mencakup: 1) Dimensi Pembangunan Manusia, yang terdiri dari bidang pendidikan; kesehatan; perumahan dan mental/karakter; 2) Dimensi Pembangunan Sektor Unggulan, yang meliputi kedaulatan pangan; kedaulatan energi dan ketenagalistrikan; kemaritiman dan kelautan; dan pariwisata dan industri; dan 3) Dimensi Pemerataan dan Kewilayahan, yang meliputi pemerataan pendapatan antar kelompok dan antar wilayah: desa, pinggiran, luar Jawa, dan kawasan timur.

Sampel penelitian ini terdiri dari lima (5) edisi surat kabar tiap bulan. Unit analisis dalam kajian ini adalah seluruh rubrik yang berkaitan dengan pemberitaan kebijakan pemerintahan (kementerian/lembaga, baik pusat maupun daerah dalam bidang sosial, ekonomi, budaya, politik dan pertahanan keamanan). Edisi yang diambil tergambar pada tabel berikut ini.

Tabel 1. Jumlah Sampel Analisis Media pada Masing-Masing Surat Kabar

\begin{tabular}{lccccc}
\hline \multirow{2}{*}{ BULAN } & \multicolumn{5}{c}{ MINGGU } \\
\cline { 2 - 6 } & I & II & III & IV & V \\
\hline JANUARI & $1-8$ & $9-15$ & $16-22$ & $23-29$ & $30-31$ \\
FEBRUARI & $1-5$ & $6-12$ & $13-19$ & $20-26$ & $27-28$ \\
MARET & $1-5$ & $6-12$ & $13-19$ & $20-26$ & $27-31$ \\
APRIL & $1-2$ & $3-9$ & $10-16$ & $17-23$ & $24-30$ \\
MEI & $1-7$ & $8-14$ & $15-21$ & $22-28$ & $29-31$ \\
JUNI & $1-4$ & $5-11$ & $12-18$ & $19-25$ & $26-30$ \\
JULI & $1-2$ & $3-9$ & $10-16$ & $17-23$ & $24-31$ \\
AGUSTUS & $1-6$ & $7-13$ & $14-20$ & $21-27$ & $28-31$ \\
SEPTEMBER & $1-3$ & $4-10$ & $11-17$ & $18-24$ & $25-30$ \\
& & & & &
\end{tabular}

Untuk menentukan kategorisasi berita yang memenuhi unsur kebijakan pemerintah pusat ataupun daerah, maka setiap bulan Tim Pelaksana Kegiatan Analisis Media menyatukan pendapat tentang berita-berita yang memenuhi syarat kualifikasi sebagai sampel penelitian.

Uji reliabilitas sangat penting dilakukan untuk melihat sejauh mana tingkat konsistensi pengukuran data dari berita-berita surat kabar yang muncul, yakni untuk memenuhi syarat objektivitas hasil coding antar petugas coding. Adapun rumus yang dipakai dalam menghitung tingkat kepercayaan antar petugas coding adalah intercoder reliability dari Holsti yaitu: $\quad \mathrm{CR}=2 \mathrm{M} /(\mathrm{N} 1+\mathrm{N} 2)$. Kesamaan skor reliabilitas antar petugas coding sebaiknya berkisar antara 70-80 persen, sehingga proses coding dapat diterima atau dapat dipercaya (Bulaeng, 2004).

\section{HASIL DAN PEMBAHASAN}

Berdasarkan sampel terpilih, ditetapkan 812 sampel berita terkait kebijakan pemerintah, yaitu surat kabar Pikiran Rakyat sebanyak 224 sampel atau 24,88\% sampel per bulan, Radar Banten 206 sampel atau 22,88\% sampel per bulan, Sumatera Ekspres 180 sampel atau 20,00\% sampel per bulan, dan Tribun Lampung 202 sampel atau 22,44\% sampel per bulan. Agenda keempat surat kabar tersebut memiliki kesamaan, yakni untuk memengaruhi audiens dan berinteraksi dengan mereka mengenai berita kebijakan pemerintah.

Frekuensi pemberitaan banyak dipengaruhi oleh peristiwa yang terjadi di daerah setempat, terlebih apabila peristiwa tersebut dihadiri oleh pejabat eksekutif atau non eksekutif sebagai narasumber dari pusat 
yang merupakan figur yang menarik untuk diliput media. Pemberitaan juga dapat dipengaruhi oleh dinamika kejadian yang sedang menjadi trending issue di masyarakat, sehingga diangkat menjadi agenda berita surat kabar. Adapun hasil uji reliabilitas antar dua petugas coding, terpapar pada tabel berikut ini.

Tabel 2. Uji Reliabilitas Antar Petugas Coding

\begin{tabular}{|c|c|c|c|}
\hline $\begin{array}{l}\text { Kategori Dimensi } \\
\text { Pembangunan }\end{array}$ & Unit Analisis & $\begin{array}{c}\text { Uji Reliabilitas } \\
\text { CR=2M/(N1+N2) }\end{array}$ & Persentase Persetujuan \\
\hline \multirow[t]{2}{*}{ Pembangunan Manusia } & $\begin{array}{l}\text { Pembangunan Manusia dan } \\
\text { Masyarakat }\end{array}$ & $2(691,5) / 812+812$ & 0,80 \\
\hline & Revolusi Mental & $2(730,1) / 812+812$ & 0,85 \\
\hline Pembangunan & Kedaulatan Pangan & $2(797,0) / 812+812$ & 0,93 \\
\hline \multirow[t]{3}{*}{ Unggulan } & Kedaulatan Energi & $2(691,5) / 812+812$ & 0,80 \\
\hline & Pembangunan Kemaritiman & $2 \overline{(797,2) / 812+812}$ & 0,93 \\
\hline & $\begin{array}{l}\text { Pembangunan Karakter dan } \\
\text { Potensi Pariwisata }\end{array}$ & $2(844,2) / 812+812$ & 0,98 \\
\hline \multirow{3}{*}{$\begin{array}{l}\text { Dimensi Pemerataan } \\
\text { Kewilayahan }\end{array}$} & $\begin{array}{l}\text { Pembangunan Kawasan } \\
\text { Perbatasan }\end{array}$ & $2(789,3) / 812+812$ & 0,92 \\
\hline & Pembangunan Desa dan & $2(\underline{704,5}) / 812+812$ & 0,82 \\
\hline & $\begin{array}{l}\text { Kawasan Perdesaan } \\
\text { Pengembangan Tata Kelola } \\
\text { Pemda dan Otonomi Daerah }\end{array}$ & $2(834,2) / 812+812$ & 0,97 \\
\hline
\end{tabular}

Sumber: Hasil Penelitian (diolah). 2017.

Dari hasil uji reliabilitas tergambar bahwa seluruh topik berita yang dijadikan sampel di empat surat kabar tersebut memiliki nilai lebih dari 0,85 dari rentang toleransi nilai minimum antara 0,70 atau $70 \%$ sehingga dipandang reliabel karena memiliki tingkat kepercayaan melebihi 80\%. Dengan demikian, kategori unit analisis yang diambil pada pemberitaan tentang kebijakan dan program pemerintah pusat ataupun daerah dalam membentuk citra masyarakat oleh kedua petugas coding adalah valid.

\section{Agenda Setting Media}

Rubrikasi penempatan berita di empat surat kabar dalam periode bulan Januari sampai September 2017 tergambar pada tabel berikut.

Tabel 3. Rubrikasi Penempatan Berita

\begin{tabular}{lllllc}
\hline \multirow{2}{*}{$\begin{array}{l}\text { Rubrikasi } \\
\text { Penempatan }\end{array}$} & \multicolumn{3}{c}{ Nama Surat Kabar } & Total \\
\cline { 2 - 5 } & $\begin{array}{l}\text { Pikiran } \\
\text { Rakyat }\end{array}$ & Radar Banten & $\begin{array}{c}\text { Sumatera } \\
\text { Ekspres }\end{array}$ & $\begin{array}{c}\text { Tribun } \\
\text { Lampung }\end{array}$ & Jumlah \\
\hline 1) Headline & $22 / 9,8 \%$ & $15 / 7,3 \%$ & $25 / 13,9 \%$ & $4 / 2,0 \%$ & $66 / 8,1 \%$ \\
2) Kolom Opini & $5 / 2,2 \%$ & $0 / 0 \%$ & $8 / 4,4 \%$ & $4 / 2,0 \%$ & $17 / 2,1 \%$ \\
3) Rubrik Politik & $5 / 2,2 \%$ & $62,9 \%$ & $38 / 21,1 \%$ & $7 / 3,5 \%$ & $56 / 6,9 \%$ \\
4) Rubrik Ekonomi & $53 / 23,7 \%$ & $35 / 17,0 \%$ & $55 / 30,6 \%$ & $31 / 15,3 \%$ & $174 / 21,4 \%$ \\
5) Rubrik Sosial & & & & & $211 / 26,6 \%$ \\
Pendidikan & $131 / 58,5 \%$ & $46 / 22,3 \%$ & $26 / 14,4 \%$ & $8 / 4,0 \%$ & $12 / 1,5 \%$ \\
6) Rubrik Budaya & $5 / 2,2 \%$ & $1 / 0,5 \%$ & $6 / 3,3 \%$ & $0 / 0 \%$ &
\end{tabular}


Analisis Wacana Media Terhadap Kebijakan dan Citra Pemerintah di Surat Kabar Daerah Pada Tahun 2017 Syarif Budhirianto, Noneng Sumiaty, Syaidah

\begin{tabular}{clllll}
\hline 7) Rubrik Hiburan & $0 / 0 \%$ & $1 / 0,5 \%$ & $0 / 0 \%$ & $0 / 0 \%$ & $1 / 0,1 \%$ \\
8) Lainnya & $3 / 1,3 \%$ & $102 / 49,5 \%$ & $22 / 12,2 \%$ & $148 / 73,3 \%$ & $275 / 33,9 \%$ \\
\hline Total & $224 / 100 \%$ & $206 / 100 \%$ & $180 / 100 \%$ & $202 / 100 \%$ & $812 / 100 \%$ \\
\hline
\end{tabular}

Sumber: Hasil Penelitian. 2017.

Rubrikasi penempatan berita terbanyak adalah pada rubrik sosial, pendidikan, disusul dengan rubrik ekonomi. Hal ini sejalan dengan konsep Nawacita yang dicanangkan oleh Presiden Jokowi dalam bidang pendidikan dan sosial sebagai basis pembangunan sumber daya manusia (SDM) dalam menghadapi tantangan pembangunan bangsa di masa depan. Dengan demikian, Indonesia diharapkan mampu menghadapi persaingan global ekonomi dengan negara lain.

Ruang lingkup berita sebagian besar merupakan berita regional, yakni sebanyak $658(81,09 \%)$ berita, selanjutnya berita nasional $149(18,3 \%)$ berita, dan sebagian kecil lainnya merupakan berita internasional, yakni sebanyak $5(0,6 \%)$ berita. Hal tersebut menggambarkan bahwa agenda setting media lebih mengedepankan unsur proksimitas (kedaerahan) sebagai trending topic, dengan harapan agar audiens akan mengetahui dinamika kejadian sosial yang terjadi di sekitarnya.

Hal ini tergambar dari 57 pejabat negara yang sering diberitakan di surat kabar untuk melaksanakan program atau kebijakan. Dari jumlah tersebut, ada 6 yang dinilai dominan, yaitu bupati (berasal dari pemerintah kabupaten) sebanyak 51 berita (7,2\%), selanjutnya walikota (dari pemerintah kota) sebanyak 20 berita (2,8\%), gubernur (pemerintah propinsi) sebanyak 29 berita $(4,1 \%)$, Kementerian Pendidikan dan Kebudayaan 26 berita (3,7\%), Kementerian
Dalam Negeri 19 berita (2,7\%), dan Presiden 16 berita $(2,3 \%)$. Adapun persentase berita dari kementerian lain berkisar antara 1-2\%. Hal tersebut memperlihatkan bahwa keempat surat kabar lebih banyak menampilkan pejabat daerahnya dibanding pejabat pemerintah pusat, karena agenda setting media lebih memprioritaskan pejabat daerah sebagai spokesperson dan sekaligus eksekutor kebijakan, baik dari pusat maupun daerah.

Pejabat pemerintah pusat melaksanakan program dan kebijakan nasional sehingga frekuensi pemberitaannya di media lokal relatif kurang dibanding pejabat daerah. Dari sisi proksimitas, posisi bupati, walikota, dan gubernur lebih unggul dibandingkan pejabat nasional karena lebih mengetahui situasi dan kondisi masyarakat serta infrastruktur dalam menunjang perekonomiannya. Topik berita yang dimunculkan pada keempat surat kabar tersebut tampak pada gambar berikut ini.

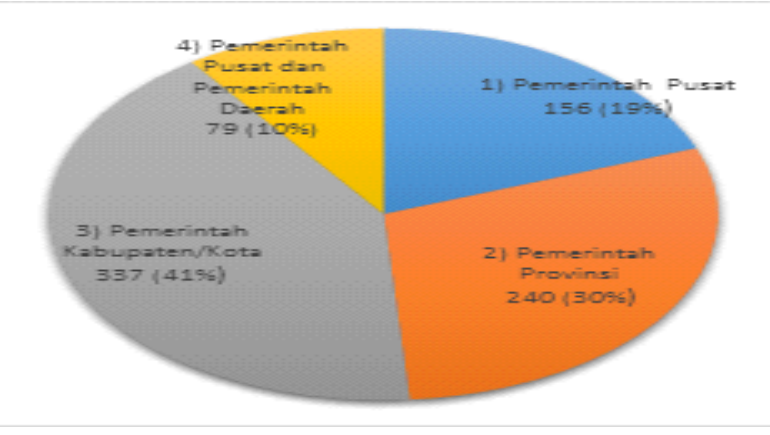

Gambar 2. Topik Berita menurut Kategori Pemerintah 
Dari rincian tentang topik berita berdasarkan kategori, tampak bahwa proporsi berita terbanyak berasal dari pemerintah kabupaten/kota, kemudian dari pemerintah provinsi, dan sebagian kecil lainnya dari pemerintah pusat dan daerah. Ini menunjukkan bahwa agenda setting empat surat kabar tersebut lebih memprioritaskan informasi yang ada di daerahnya dibanding informasi di tingkat nasional. Dinamika daerah dinilai lebih urgen disampaikan kepada masyarakat. Berita daerah juga akan melahirkan transparansi di kalangan masyarakat tentang tata kelola pemerintahan yang bersih, efektif, dan demokratis sehingga dapat meningkatkan kepercayaan masyarakat.

Tabel 4. Fokus Berita Program dan Kebijakan

\begin{tabular}{|c|c|c|c|c|c|}
\hline \multirow{2}{*}{$\begin{array}{c}\text { Fokus Pemberitaan dalam Frame } \\
\text { Media }\end{array}$} & \multicolumn{4}{|c|}{ Nama Surat Kabar } & \multirow[b]{2}{*}{ Total } \\
\hline & $\begin{array}{l}\text { Pikiran } \\
\text { Rakyat }\end{array}$ & $\begin{array}{l}\text { Radar } \\
\text { Banten }\end{array}$ & $\begin{array}{c}\text { Sumatera } \\
\text { Ekspres }\end{array}$ & $\begin{array}{c}\text { Tribun } \\
\text { Lampung }\end{array}$ & \\
\hline $\begin{array}{l}\text { Pembangunan Kesehatan/Pengendalian } \\
\text { Penyakit }\end{array}$ & $4 / 1,8 \%$ & $10 / 4,8 \%$ & $8 / 4,2 \%$ & $18 / 8,8 \%$ & $40 / 4,9 \%$ \\
\hline $\begin{array}{l}\text { Kesetaraan Gender, Pemberdayaan } \\
\text { Perempuan dan Perlindungan anak }\end{array}$ & $1 / 0,4 \%$ & $0 / 0,0 \%$ & $2 / 1,1 \%$ & $1 / 0,5 \%$ & $4 / 0,5 \%$ \\
\hline Pembangunan Masyarakat & $57 / 25,4 \%$ & $64 / 30,9 \%$ & $11 / 5,8 \%$ & $18 / 8,8 \%$ & $150 / 18,5 \%$ \\
\hline Kedaulatan Pangan & $22 / 9,8 \%$ & $7 / 3,4 \%$ & $2 / / 1,1 \%$ & $14 / 6,8 \%$ & $45 / 5,5 \%$ \\
\hline Kedaulatan Energi & $10 / 4,5 \%$ & $4 / 1,9 \%$ & $6 / 3,2 \%$ & $0 / 0,0 \%$ & $20 / 2,5 \%$ \\
\hline Maritim dan Kelautan & $2 / 0,9 \%$ & $3 / 1,4 \%$ & $2 / 1,1 \%$ & $4 / 2,0 \%$ & $11 / 1,4 \%$ \\
\hline Infrastruktur Dasar dan Konektivitas & $17 / 7,6 \%$ & $22 / 10,6 \%$ & $26 / 13,8 \%$ & $48 / 23,4 \%$ & $113 / 13,9 \%$ \\
\hline Lingkungan & $47 / 21,0 \%$ & $4 / 1,9 \%$ & $6 / 3,2 \%$ & $3 / 1,5 \%$ & $60 / 7,4 \%$ \\
\hline Kesenjangan Antar Kelompok Ekonomi & $20 / 8,9 \%$ & $5 / 2,4 \%$ & $15 / 7,9 \%$ & $4 / 2,4 \%$ & $44 / 5,4 \%$ \\
\hline $\begin{array}{l}\text { Peningkatan Daya Saing Tenaga } \\
\text { Kerja/Program Ketenagakerjaan }\end{array}$ & $3 / 1,3 \%$ & $1 / 0,5 \%$ & $16 / 8,5 \%$ & $3 / 0,5 \% \wedge$ & $23 / 2,8 \%$ \\
\hline Peningkatan Kualitas dan Keterampilan & $22 / 9,8 \%$ & $2 / 1,0 \%$ & $3 / 1,6 \%$ & $5 / 0,5 \%$ & $32 / 3,9 \%$ \\
\hline Pembangunan Perdesaan & $0 / 0,0 \%$ & $3 / 1,4 \%$ & $15 / / 7,9 \%$ & $1 / 0,5 \%$ & $19 / 2,3 \%$ \\
\hline Pengembangan Kawasan Perbatasan & $1 / 0,4 \%$ & $0 / 0,0 \%$ & $2 / 1,1 \%$ & $1 / 0,5 \%$ & $4 / 0,5 \%$ \\
\hline Pengembangan Daerah Tertinggal & $2 / 0,9 \%$ & $1 / 0,5 \%$ & $6 / 3,2 \%$ & $2 / 1,0 \%$ & $11 / 1,4 \%$ \\
\hline $\begin{array}{l}\text { Pembangunan Pusat-Pusat Pertumbuhan } \\
\text { Ekonomi di Luar Jawa }\end{array}$ & $1 / 0,4 \%$ & $0 / 0,0 \%$ & $13 / 6,9 \%$ & $15 / 7,3 \%$ & $29 / 3,6 \%$ \\
\hline Pembangunan Kawasan Perkotaan. & $13 / 5,8 \%$ & $6 / 2,9 \%$ & $3 / 1,6 \%$ & $13 / 6,3 \%$ & $35 / 4,3 \%$ \\
\hline Lainnya........ & $2 / 0,8 \%$ & $75 / 36,2 \%$ & $53 / 28,0 \%$ & $55 / 26,8$ & $185 / 22,8 \%$ \\
\hline Total & $224 / 100 \%$ & $207 / 100,0 \%$ & $189 / 100,0 \%$ & $205 / 100.0 \%$ & $825 / 100,0 \%$ \\
\hline
\end{tabular}

Sumber: Hasil Penelitian. 2017.

Fokus pemberitaan lebih menonjolkan pembangunan masyarakat, diikuti dengan infrastruktur dan konektivitas dan pemberitaan lainnya. Pemberitaan tentang pembangunan masyarakat (dimensi pembangunan manusia) merupakan hal yang urgen dalam agenda media 
keempat surat kabar tersebut karena dapat meningkatkan kualitas sumber daya manusia Indonesia. Liputan berita tersebut sebagian besar menonjolkan isu peningkatan kesehatan masyarakat dan kemudahan akses ke pusat pelayanan kesehatan. Penyakit langka dan obat bebas adalah contoh masalah yang sering diangkat. Pemberitaan ini diharapkan akan berkontribusi untuk pembuatan kebijakan yang tepat.

$\begin{array}{cc}\text { Adapun pemberitaan } & \text { mengenai } \\ \text { infrastruktur dan konektivitas } & \text { (dimensi }\end{array}$ pemerataan dan kewilayahan) berhubungan dengan pertumbuhan aktivitas ekonomi masyarakat sebagai basis kekuatan yang pokok, serta peningkatan cakupan pelayanan dasar dan akses terhadap ekonomi produktif masyarakat kurang mampu. Di dalamnya juga tercakup pentingnya peningkatan daya saing tenaga kerja, kepesertaan program ketenagakerjaan, dan peningkatan kualitas dan keterampilan pekerja. Adapun pemberitaan tentang isu konektivitas meliputi pembangunan perdesaan, pengembangan kawasan perbatasan, pengembangan daerah tertinggal, pembangunan pusat pertumbuhan ekonomi di luar Jawa, dan pembangunan kawasan perkotaan.

\section{Pemberitaan Media dan Pengaruh Pemberitaan Media tentang Kebijakan Pemerintah terhadap Citra Pemerintah}

Surat kabar sudah menjadi media penyampai berita, penilaian dan pembentukan citra tentang banyak hal sehingga berperan sebagai institusi yang membentuk opini publik. Adapun pencitraan masyarakat dalam beritanya sudah berdasar pada realitas media yang dikonstruksikan dalam bentuk wacana yang bermakna.

Untuk mengetahui kesesuaian berita dengan program kebijakan pemerintah di media surat kabar dapat dilihat dalam tabel berikut ini.

Tabel 5. Citra Program Pemerintah dalam Pemberitaan Surat Kabar

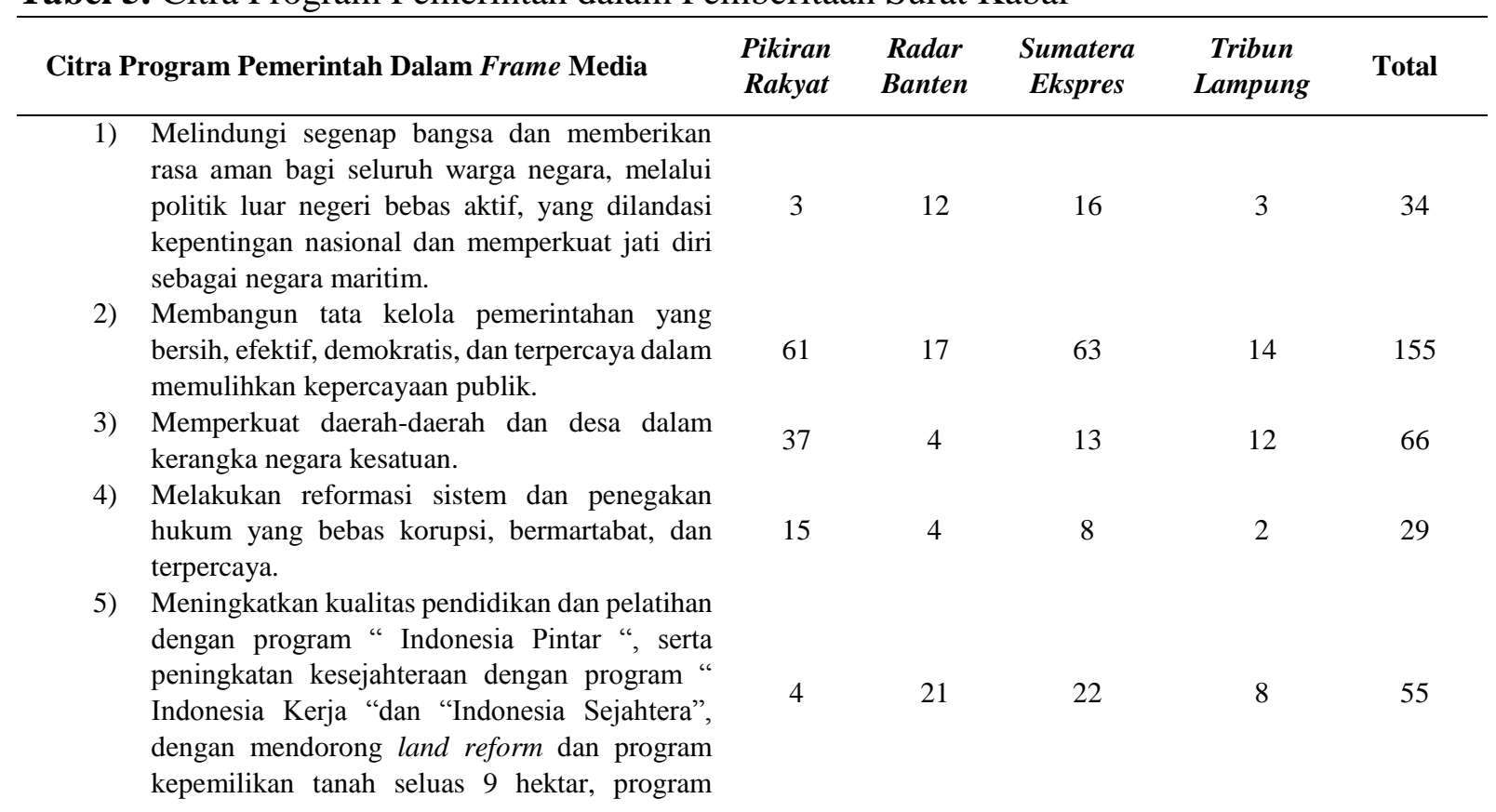


rumah kampung atau rumah susun murah bersubsidi serta jaminan sosial di tahun 2019.

6) Meningkatkan produktivitas rakyat dan daya saing internasional, sehingga Indonesia bisa maju dan bangkit bersama bangsa lainnya.

7) Mewujudkan kemandirian ekonomi dengan menggerakkan sektor-sektor strategis ekonomi domestik.

8) Melakukan revolusi karakter bangsa dengan menata kembali kurikulum pendidikan nasional dengan mengedepankan aspek kewarganegaraan.

9) Memperteguh kebhinekaan dan memperkuat restorasi sosial Indonesia melalui pendidikan kebhinekaan dan menciptakan ruang dialog antar warga.

\begin{tabular}{rllllll}
\hline Total & 201 & 93 & 160 & 79 & 533 \\
\hline
\end{tabular}

Pemerintah dicitrakan berupaya membangun tata kelola pemerintahan yang bersih, efektif, demokratis, dan terpercaya sehingga dapat meningkatkan kepercayaan publik. Hal ini merupakan prasyarat untuk menegakkan pemerintah yang bersih (good government) dan diharapkan dapat menjawab segala permasalahan yang dihadapi masyarakat. Dalam hal ini, pembangunan di bidang ekonomi yang menekankan pada kemandirian ekonomi dengan menggerakkan sektor-sektor strategis ekonomi domestik menjadi salah satu prioritas utama program pemerintah. Sasaran penting program kemandirian ekonomi adalah masyarakat pinggiran, terluar, dan perbatasan.

Dari pencitraan lembaga pemerintah tersebut tampak bahwa setiap informasi tentang program dan kebijakan yang dilakukan oleh lembaga pemerintah memberikan citra yang yang positif kepada pemerintahan Joko Widodo-Jusuf Kalla. Citra yang positif ini seringkali dihubunghubungkan oleh sejumlah pengamat politik dengan konstelasi politik tahun 2019 yang akan datang.

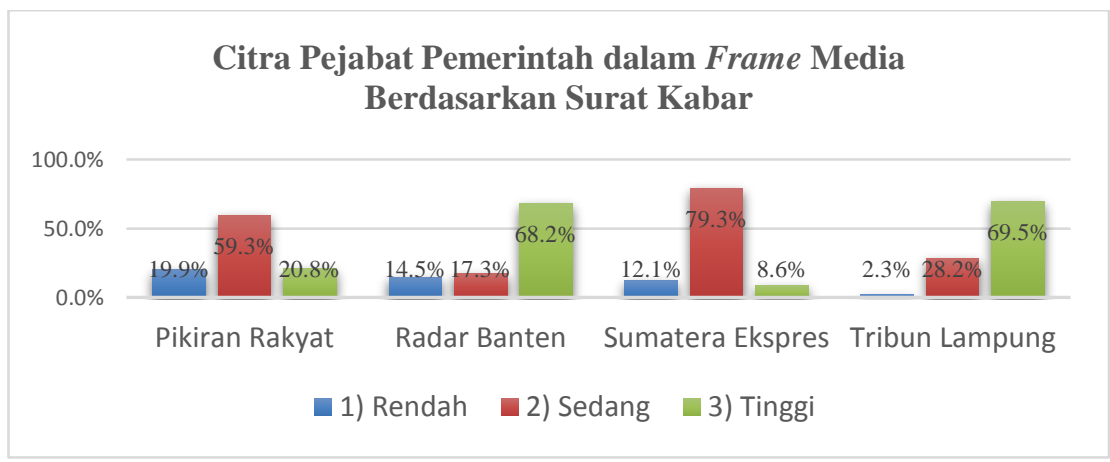

Gambar 3. Citra Pejabat Pemerintah dalam Pemberitaan Surat Kabar

Dalam kategori pencitraan para pejabat pemerintah, bingkai media menyatakan sebagian besar berada dalam kategori sedang, dan hanya sebagian kecil saja 
yang berkategori rendah. Adapun persentase jumlah pemberitaan pejabat pemerintah di tiap surat kabar adalah sebagai berikut: (1) Kategori sedang, sebagian besar dari surat kabar Sumatera Ekspres; Pikiran Rakyat; Tribun Lampung; dan Radar Banten; (2) Kategori tinggi, sebagian besar dari surat kabar Tribun Lampung; Radar Banten; Pikiran Rakyat; dan Sumatera Ekspres; (3). Kategori rendah, berasal dari Pikiran Rakyat; Radar Banten; Sumatera Ekspres; dan Tribun Lampung. Tingginya apresiasi terhadap pemberitaan di keempat surat kabar tersebut menunjukkan bahwa khalayak pembaca menaruh rasa hormat terhadap pejabat pemerintah dengan berbagai program dan kebijakan yang mereka lakukan, terlebih jika perencanaannya dilakukan sesuai harapan masyarakat. Hal ini tentunya akan mendapat dukungan yang baik pula.

\section{Sikap Media}

Untuk mengetahui arah keberpihakan keempat surat kabar tersebut, akan dilakukan pengukuran dengan indikator sebagai berikut: sumber informasi utama/dominan, atribut pejabat, sumber informasi lainnya, tokoh utama dalam berita, tone berita secara keseluruhan, serta keberimbangan berita.

Tabel 6. Sumber Informasi Utama Berita Surat Kabar

\begin{tabular}{|c|c|c|c|c|c|}
\hline Sumber Informasi Utama Berita & $\begin{array}{l}\text { Pikiran } \\
\text { Rakyat }\end{array}$ & $\begin{array}{r}\text { Radar } \\
\text { Banten }\end{array}$ & $\begin{array}{c}\text { Sumatera } \\
\text { Ekspres }\end{array}$ & $\begin{array}{c}\text { Tribun } \\
\text { Lampung }\end{array}$ & Total \\
\hline Eksekutif: Pusat dan Daerah dan seterusnya. & 120 & 158 & 63 & 165 & 506 \\
\hline Yudikatif: Pejabat Peradilan, Jaksa Agung & 8 & 5 & 34 & 1 & 48 \\
\hline Legislatif & 40 & 15 & 23 & 11 & 89 \\
\hline $\begin{array}{l}\text { Media: Wartawan itu sendiri } \\
\text { Masyarakat: Anggota Masyarakat, LSM, Tokoh }\end{array}$ & 31 & 4 & 29 & 1 & 65 \\
\hline Masyarakat dan seterusnya. & 17 & 24 & 31 & 23 & 95 \\
\hline Tidak Ada Kutipan. & 8 & 0 & 0 & 1 & 9 \\
\hline Total & 224 & 206 & 180 & 202 & 812 \\
\hline
\end{tabular}

Sumber: Hasil Penelitian. 2017.

Sumber informasi utama tentang program kebijakan pemerintah yang diberitakan pada empat surat kabar sebagian besar berasal dari eksekutif pusat dan daerah. Hal ini disebabkan adanya rencana pembangunan nasional (RPJM) yang disusun lembaga eksekutif setiap tahunnya berbasis anggaran yang diperoleh. Lembaga lainnya seperti lembaga legislatif, yudikatif, media, dan kelompok masyarakat lainnya tidak mempunyai rencana kerja serupa. Persentase terbesar pemberitaan lembaga eksekutif sebagai sumber informasi utama berasal dari surat kabar Tribun Lampung dan sebagian kecil dari surat kabar Sumatera Ekspres. Adanya perbedaan persentase dalam pemberitaan sumber informasi pada keempat surat kabar disebabkan oleh perbedaan prioritas pemberitaan di setiap daerah.

Umumnya sumber pemberitaan program kebijakan pemerintah di surat kabar bukan hanya satu orang karena pada hakekatnya diperlukan sinergi antar lembaga dalam menjalankan kebijakan pemerintah. Dilihat dari konten berita, kecenderungan terhadap berita tersebut tergambar pada tabel berikut. 
Tabel 7. Nada Pemberitaan

\begin{tabular}{cccccc}
\hline \multicolumn{1}{c}{ Nada Berita } & $\begin{array}{l}\text { Pikiran } \\
\text { Rakyat }\end{array}$ & $\begin{array}{l}\text { Radar } \\
\text { Banten }\end{array}$ & $\begin{array}{l}\text { Sumatera } \\
\text { Ekspres }\end{array}$ & $\begin{array}{l}\text { Tribun } \\
\text { Lampung }\end{array}$ & Total \\
\hline Mendukung (positif) & 121 & 172 & 122 & 197 & $612(75,4 \%)$ \\
Tidak Mendukung (negatif) & 42 & 11 & 27 & 1 & $81(10,0 \%)$ \\
Tidak Berpihak (netral) & 61 & 23 & 31 & 4 & $119(14,7 \%)$ \\
\hline Total & 224 & 206 & 180 & 202 & $812(100,0 \%)$ \\
\hline
\end{tabular}

Sumber: Hasil Penelitian. 2017.

Dari tabel di atas tampak bahwa sebagian besar nada pemberitaan program dan kebijakan pemerintah pusat dan daerah cenderung positif. Hal ini menunjukkan bahwa berita tersebut mendapat apresiasi yang baik dari masyarakat, dan hanya sebagian kecil berita yang tampak tidak mendukung atau menunjukkan sentimen negatif. Adapun nada pemberitaan yang tidak berpihak (netral) merupakan sikap tengah yang dapat dimaknai mengarah pada sikap negatif.

\section{KESIMPULAN DAN SARAN}

Konstruksi agenda setting surat kabar pada pemberitaan program dan kebijakan pemerintah pusat dan daerah telah membentuk pencitraan terhadap program dan kebijakan pemerintah saat ini. Hal ini tergambar pada porsi pemberitaan yang lebih menitikberatkan berita tentang pembangunan masyarakat dan ekonomi, yang sejalan dengan prinsip Nawacita yang dicanangkan pemerintah. Di samping itu, tampak bahwa berita regional lebih mendominasi pemberitaan surat kabar dibandingkan berita nasional dan internasional. Dengan kata lain, redaksi empat surat kabar tersebut menilai bahwa unsur proksimitas dalam pemberitaan lebih penting bagi masyarakat.

Surat kabar telah menjadi alat penyampai berita, penilai dan pembentuk citra dan institusi pembentuk opini publik, seperti ditunjukkan oleh pembingkaian berita keempat surat kabar yang lebih berpihak kepada kepentingan masyarakat dan sebagian kecil lainnya pada pemerintah, industri dan parpol. Pemberitaan yang diutamakan dalam konteks tersebut adalah mengenai sistem pelayanan publik yang baik, khususnya terkait dengan upaya membangun tata kelola pemerintahan yang bersih, efektif, demokratis dan terpercaya guna memulihkan kepercayaan masyarakat.

Sikap keberpihakan surat kabar sebagai sumber informasi utama tergambar pada nada pemberitaan yang menunjukkan penilaian berita terhadap sebuah peristiwa atau realitas tertentu. Dalam studi ini, sebagian besar konten berita dari keempat surat kabar tersebut memiliki kecenderungan mendukung (positif). Hanya sebagian kecil berita yang memperlihatkan ketidakberpihakan. Adapun persentase terbesar pemberitaan yang mendukung program dan kebijakan pemerintah berasal dari surat kabar Tribun Lampung dan sebagian kecil lainnya dari surat kabar Pikiran Rakyat.

Agar agenda setting media dapat sejalan dengan agenda publik, hendaknya surat kabar memahami kebutuhan informasi publiknya. Dalam hal ini, sekalipun menurut perspektif agenda setting kepemilikan media dipandang sebagai faktor yang turut menentukan tone pemberitaan media, surat kabar harus menyajikan informasi yang objektif dan independen.

Penting untuk diingat bahwa media massa punya potensi untuk bersikap tidak netral karena besarnya peluang intervensi dari pemilik modal terhadap pemberitaan media tersebut. Curran \& Gurevitch (1982), 
mengatakan bahwa kepentingan pemilik media dikhawatirkan akan melahirkan hegemoni ideologi media sehingga pada akhirnya akan memengaruhi pesan yang disampaikan media kepada khalayak (Subiakto, Ida, 2012).

\section{UCAPAN TERIMA KASIH}

Penelitian ini dapat kami selesaikan sesuai dengan timeline yang direncanakan, untuk itu ucapan terima kasih dan penghargaan yang setulus-tulusnya disampaikan kepada Tim Pelaksana Kegiatan Analisis Media Tahun 2017 yang telah membantu menyusun penelitian ini. Ucapan terima kasih juga kami sampaikan kepada pengelola perpustakaan BPSDMP Bandung yang telah memberikan bantuan referensi dan sumber bacaan lainnya sehingga tulisan ini dapat diselesaikan dengan baik.

\section{DAFTAR PUSTAKA}

Akbar, Arif, J. P., \& Sasongko, D. (2015). Seratus Hari Jokowi di Mata Media. Pindai: Kritis Dan Mendalam. Diakses dari https://www.slideshare.net/pindai/100hari-jokowi-di-mata-media pada tanggal 20 September 2017.

Ali, D. J. (2015). Paska Setahun Jokowi-JK Dibutuhkan Menteri Utama, Lingkaran survei Indonesia. Diakses dari http://lsi.co.id/lsi/wpcontent/uploads/2015/10/Konpers-PaskaSetahun-Jokowi- -JK.pdf pada tanggal 18 September 2017.

Alma, B. (2009). Manajemen Pemasaran dan Pemasaran Jasa. CV. Alfabeta: Bandung.

Bulaeng, A. (2004). Metode Penelitian Komunikasi Kontemporer. Yogyakarta: Andi.

Dalilah, D. (2015). Konstruksi Pemberitaan Media Online Tentang Kinerja Kabinet
Kerja Jokowi-JK (Analisis Framing pada News Media Online detik.com \& VIVA.co.id Edisi 26 Oktober 2015. Diakses dari http://eprints.umm.ac.id/20952/ pada tanggal 18 September 2017.

Kriyantono, R. (2007). Teknik Praktis riset Komunikasi. Jakarta: Kakilangit Kencana.

Littlejohn, S.W. (2005). Theories of Human Communication. Seventh Edition, California: Wadsworth Publishing.

McCombs, M.E. (1972). Mass Communication in Political Campaigns: Information, Gratification and Persuasion. In: Kline, F. \& Tichenor, Ph.J. (Eds.) Current Perspectives in Mass Communication Research. Beverly Hills, CA.: Sage.

Rakhmat, J. (2007). Psikologi Komunikasi. Bandung: Remaja Rosdakarya.

Ramsden, G. P. (1992). Local Press Coverage of The Iowa Caucus Campaign. The Univercity of Iowa.

Subiakto, H. \& Rachmah, I. (2012). Komunikasi Politik, Media, \& demokrasi. Jakarta: Kencana Prenada Media Group.

Tamburaka, A. (2012). Agenda Setting Media Massa. Jakarta: Rajawali Pers.

Zinkhan, G., Ganesh, J., \& Hayes, L. (2001). Corporate Imagea; A Conceptual Framework for Strategic Planning. Proceedings of AMA (Writer) Marketing Educators Conference. 
Jurnal PIKOM (Penelitian Komunikasi dan Pembangunan)

Vol. 19 No. 2 Desember 2018 